\title{
Research on the Evaluation Index for Construction Enterprise's Technological Innovation Using Analytical Network Process Method
}

\author{
Jing TENG ${ }^{1, a,{ }^{*},}$ Qin FU ${ }^{2, b}$, Yao CHEN ${ }^{3, c}$, Wan-Ling ZOU ${ }^{4, d}$ \\ ${ }^{1,2,3,4}$ Xihua University of Architecture and Civil Engineering, Chengdu, Sichuan, China 610039 \\ ajj10300817@163.com, b995928525@qq.com, c348244696@qq.com, ${ }^{\text {d } 1274640422 ~ @ q q . c o m ~}$ \\ ${ }^{*}$ Corresponding author
}

Keywords: Construction enterprise, Technological innovation, Analytic network process, Fuzzy comprehensive evaluation.

\begin{abstract}
This thesis builds a set of evaluation index system of construction enterprise technology innovation based on network analytic network process and by empowering each indicator and evaluates indicators combined with fuzzy comprehensive evaluation method, the technology innovation levels of construction enterprise are obtained.This provides a set of objective and scientific evaluation methods for construction enterprise's technological innovation ability evaluation.
\end{abstract}

\section{The establishment of the indicator system of construction enterprise technology innovation}

\section{The principles}

The establishment should be comprehensive, scientific, and applicable. The index setting should be concise, easy to operate. At the same time, in the process of practical application, the indicator system should conform to the actual situation of the construction enterprise technology innovation to demonstrate its practicality.

The establishment should combine qualitative and quantitative indicators. In the process of index setting-up, according to the principle of combining qualitative and quantitative indicators, for some indicators which are hard to be quantitatively measured, there should be the qualitative indicators to ensure the authenticity of the evaluation[1].

The establishment should combineoperability and comparability. In the process of obtaining index data, selected data should be easy to get and to deal with. Quantitative indicatorscan be directly quantified, and qualitative indicators can be indirectly quantifiedby assignment[2]. All evaluation objects should use the same evaluation standard to make them comparable.

\section{Establish indicators}

In view of construction enterprises' features, combined with the principles of building indexes, the innovation ability of construction enterprises is divided into three levels. The first grade indexes include the ability of technological innovation,capitalinput, and management innovation ability. There are 9 second grade indexes including the use of new technology and 21 third grade indexes such as the use of new construction technology, and detailed classification is shown in Table 2 .

\section{Analysis of the network relationship of construction enterprises' technical innovation indicators' system}

Analyzing the relationships among the first grade indexes, the second under each type of the first, and the third under each type of the second. The network relationships among the indexes are shown in fig.1. 


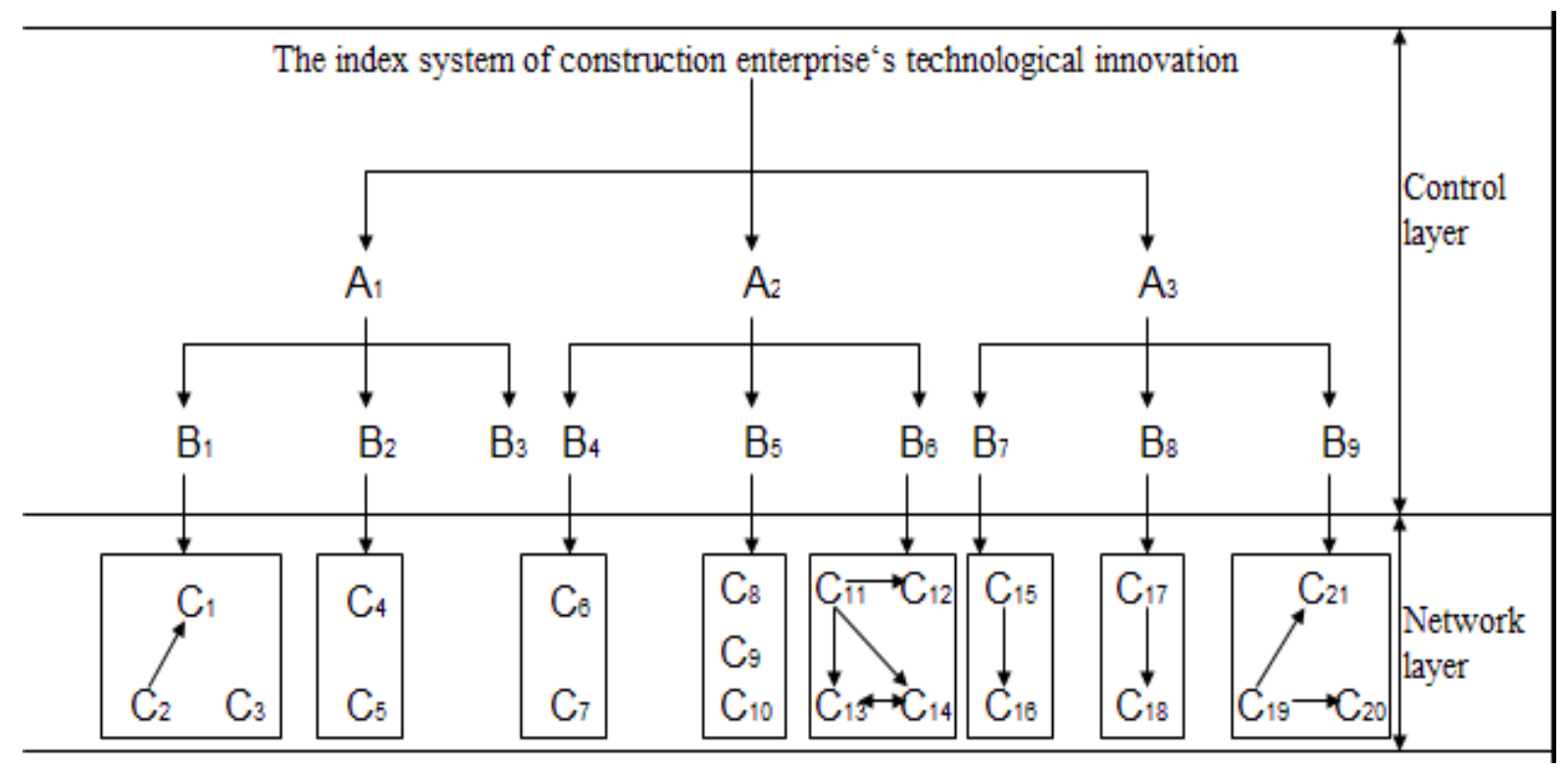

Fig. 1 Network diagram of the index system of construction enterprise's technological innovation

\section{Index weighting using analytical network process method}

Setting first grade indexes and second grade indexes as the control layer, third grade indexes as the network layer using analytical network process method. Construct multiple comparison judgment matrix using paired comparison method and measure of comparison about 1 9. Then calculating each judgment matrix's eigenvector and maximum eigenvalue $\lambda_{\max }$ using geometric mean. At last,doing the consistency check by calculating consistency index $C I$, random index $R I$, consistency ratio $C R$.If it was passed by test, eigenvector(after concentration) is weight vector;if not, we should reconstruct the comparison matrix[3].

For example, we can analyze the process of index weighting of first grade index.

\section{Multiple judgment matrix}

The multiple judgment matrix of the first grade index is shown in Table 1.

Table 1 Multiple judgment matrix for first grade index

\begin{tabular}{|c|c|c|c|}
\hline & $\begin{array}{c}\text { the ability of technological } \\
\text { Innovation }\end{array}$ & $\begin{array}{c}\text { capital } \\
\text { input }\end{array}$ & $\begin{array}{c}\text { management } \\
\text { innovation ability }\end{array}$ \\
\hline $\begin{array}{c}\text { the ability of technological } \\
\text { Innovation }\end{array}$ & 1 & 2 & 3 \\
\hline $\begin{array}{c}\text { capital input } \\
\text { management innovation } \\
\text { ability }\end{array}$ & $1 / 2$ & 1 & 3 \\
\hline
\end{tabular}


Table 2 Index classification and weight

\begin{tabular}{|c|c|c|c|c|c|c|}
\hline & $\begin{array}{l}\text { first grade } \\
\text { index }\end{array}$ & $\begin{array}{c}\text { weigh } \\
\mathrm{t}\end{array}$ & second grade index & $\begin{array}{c}\text { weigh } \\
\mathrm{t}\end{array}$ & third grade index & $\begin{array}{c}\text { weig } \\
\text { ht }\end{array}$ \\
\hline \multirow{6}{*}{$\begin{array}{l}\text { the } \\
\text { first } \\
\text { index }\end{array}$} & \multirow{6}{*}{$\begin{array}{l}\text { the ability } \\
\text { of } \\
\text { technologic } \\
\text { al } \\
\text { Innovation } \\
\mathrm{A}_{1}\end{array}$} & \multirow{6}{*}{0.528} & \multirow{3}{*}{$\begin{array}{l}\text { the use of new } \\
\text { technology } \mathrm{B}_{1}\end{array}$} & \multirow{3}{*}{0.625} & $\begin{array}{l}\text { the use of new construction } \\
\text { technology } C_{1}\end{array}$ & \multirow{3}{*}{$\begin{array}{c}0.57 \\
1\end{array}$} \\
\hline & & & & & new material $\mathrm{C}_{2}$ & \\
\hline & & & & & $\begin{array}{l}\text { the use of new detection method } \\
\text { for engineering site } C_{3}\end{array}$ & \\
\hline & & & \multirow{2}{*}{$\begin{array}{c}\text { research and } \\
\text { development of } \\
\text { new technology and } \\
\text { new material } B_{2}\end{array}$} & \multirow{2}{*}{0.238} & $\begin{array}{c}\text { research and development of new } \\
\text { construction technology } \mathrm{C}_{4}\end{array}$ & \multirow{3}{*}{$\begin{array}{c}0.66 \\
7\end{array}$} \\
\hline & & & & & $\begin{array}{c}\text { research and development of new } \\
\text { material } C_{5}\end{array}$ & \\
\hline & & & $\begin{array}{c}\text { new mechanical } \\
\text { equipment } \mathrm{B}_{3}\end{array}$ & 0.137 & & \\
\hline \multirow{9}{*}{$\begin{array}{l}\text { the } \\
\text { secon } \\
\text { d } \\
\text { index }\end{array}$} & \multirow{9}{*}{$\begin{array}{l}\text { capital } \\
\text { input } \mathrm{A}_{2}\end{array}$} & \multirow{9}{*}{0.332} & \multirow[t]{2}{*}{ innovation input $\mathrm{B}_{4}$} & \multirow[t]{2}{*}{0.54} & $\begin{array}{c}\text { technological Innovation input } \\
\text { for new technology and new } \\
\text { material } \mathrm{C}_{6}\end{array}$ & \multirow{3}{*}{$\begin{array}{c}0.66 \\
7\end{array}$} \\
\hline & & & & & $\begin{array}{c}\text { innovation input for management } \\
\qquad \mathrm{C}_{7}\end{array}$ & \\
\hline & & & \multirow{3}{*}{$\begin{array}{l}\text { adaptability to } \\
\text { changes in the } \\
\text { market } B_{5}\end{array}$} & \multirow{3}{*}{0.297} & market competitive capital $\mathrm{C}_{8}$ & \\
\hline & & & & & $\begin{array}{l}\text { reserve capital for price } \\
\text { fluctuation } \mathrm{C}_{9}\end{array}$ & \multirow{3}{*}{$\begin{array}{c}0.23 \\
2\end{array}$} \\
\hline & & & & & $\begin{array}{l}\text { capital input for brand building } \\
\qquad \mathrm{C}_{10}\end{array}$ & \\
\hline & & & \multirow{4}{*}{$\begin{array}{l}\text { capital input for } \\
\text { professional and } \\
\text { technical personnel } \\
\mathrm{B}_{6}\end{array}$} & \multirow{4}{*}{0.163} & $\begin{array}{l}\text { the proportion of professional } \\
\text { personnel } C_{11}\end{array}$ & \\
\hline & & & & & capital for talent introduction $\mathrm{C}_{12}$ & \multirow{3}{*}{$\begin{array}{c}0.26 \\
3 \\
\end{array}$} \\
\hline & & & & & \begin{tabular}{|c|} 
capital input for talent's \\
improving of professional level \\
$\mathrm{C}_{13}$
\end{tabular} & \\
\hline & & & & & $\begin{array}{c}\text { incentive capital input for talent's } \\
\text { professional level } C_{14}\end{array}$ & \\
\hline \multirow{7}{*}{$\begin{array}{l}\text { the } \\
\text { third } \\
\text { index }\end{array}$} & \multirow{7}{*}{$\begin{array}{l}\text { manageme } \\
\text { nt } \\
\text { innovation } \\
\text { ability } \mathrm{A}_{3}\end{array}$} & \multirow{7}{*}{0.14} & \multirow{2}{*}{$\begin{array}{l}\text { informatization } \\
\text { management } \\
\text { innovation } \mathrm{B}_{7}\end{array}$} & \multirow{2}{*}{0.493} & $\begin{array}{l}\text { project management } \\
\text { informatization } \mathrm{C}_{15}\end{array}$ & \multirow{3}{*}{0.5} \\
\hline & & & & & $\begin{array}{l}\text { enterprise management } \\
\text { informatization } \mathrm{C}_{16}\end{array}$ & \\
\hline & & & \multirow{2}{*}{$\begin{array}{l}\text { systematization } \\
\text { management } \\
\text { innovation } \mathrm{B}_{8}\end{array}$} & \multirow[b]{2}{*}{0.311} & enterprise lan $\mathrm{C}_{17}$ & \\
\hline & & & & & $\begin{array}{l}\text { the use of enterprise's internal } \\
\text { management platform } C_{18}\end{array}$ & \multirow{3}{*}{0.5} \\
\hline & & & \multirow{3}{*}{$\begin{array}{l}\text { management mode } \\
\text { innovation } \mathrm{B}_{9}\end{array}$} & \multirow{3}{*}{0.196} & $\begin{array}{l}\text { the ability of enterprise's } \\
\text { management innovation } C_{19}\end{array}$ & \\
\hline & & & & & $\begin{array}{c}\text { organization mechanism } \\
\text { innovation } \mathrm{C}_{20}\end{array}$ & \\
\hline & & & & & $\begin{array}{l}\text { management system innovation } \\
\qquad \mathrm{C}_{21}\end{array}$ & $\begin{array}{c}0.16 \\
3\end{array}$ \\
\hline
\end{tabular}




\section{The process of calculating first grade index's weight}

First, multiplicate each row respectively. Result: $M_{1}=1 \times 2 \times 3=6, M_{2}=\frac{1}{2} \times 1 \times 3=\frac{3}{2}$, $M_{3}=\frac{1}{3} \times \frac{1}{3} \times 1=\frac{1}{9}$. Then calculate the cude root of the product of each row. Result: $\bar{W}_{1}=\sqrt[3]{6}=1.817, \bar{W}_{2}=\sqrt[3]{\frac{3}{2}}=1.145, \bar{W}_{3}=\sqrt[3]{\frac{1}{9}}=0.481$. Then, make each vector into normalization processing , Result: $\sum_{j=1}^{3} \bar{W}_{j}=3.443$.Results Weight coefficient of the index: $W_{1}=\frac{\bar{W}_{1}}{\sum_{j=1}^{n} \bar{W}_{j}}=0.528, W_{2}=\frac{\bar{W}_{2}}{\sum_{j=1}^{n} \bar{W}_{j}}=0.333, W_{3}=\frac{\bar{W}_{3}}{\sum_{j=1}^{n} \bar{W}_{j}}=0.139$. Calculate the maximum eigenvalue $\lambda_{\max }$ of the judgment matrix: $\quad U W=\left[\begin{array}{ccc}1 & 2 & 3 \\ \frac{1}{2} & 1 & 3 \\ \frac{1}{3} & \frac{1}{3} & 1\end{array}\right]\left[\begin{array}{l}0.528 \\ 0.333 \\ 0.139\end{array}\right]=\left[\begin{array}{c}1.611 \\ 1.014 \\ 0.426\end{array}\right]$ $\lambda_{\max }=\frac{1}{n} \sum_{i=1}^{n} \frac{(U W)_{i}}{W_{i}}=\frac{1}{3}\left[\frac{(U W)_{1}}{W_{1}}+\frac{(U W)_{2}}{W_{2}}+\frac{(U W)_{3}}{W_{3}}\right]$, then do the consistency check for the judgment $=3.054$

matrix $K \rightarrow K_{i}: C I=\frac{\lambda_{\max }-\mathrm{n}}{\mathrm{n}-1}=\frac{3.054-3}{3-1}=0.0268$. Then compared with the table of mean random consistency,result, $R I=0.52$,so, $C R=\frac{C I}{R I}=0.052, \mathrm{CR}\langle 0.1$. Finally, we can make a conclusion from the calculation process aforesaid that this judgment matrix have a good consistency.We can calculate each index's weight using the method aforesaid.

\section{The fuzzy comprehensive evaluation for the evaluation index}

\section{Confirming the evaluation's factors assembly}

Make all the factors which will influent the evaluation objects into a set to construct a factor assembly of the evaluation objects $\mathrm{K}$.

$K=\left(K_{1}, K_{2}, K_{3} \ldots \ldots K_{\mathrm{n}}\right), n$ is the number, and the element is impact factor.

\section{Confirming the evaluation set}

$V=\left(V_{1}, V_{2}, V_{3} \ldots . . V_{\mathrm{m}}\right)^{T} \mathrm{~m}$ is the total number of evaluation grade. This thesis divides the grade judgment into $\quad 4 \quad$ levels, $\quad V=\left(V_{1}, V_{2}, V_{3}, V_{4}\right)^{T} \quad=($ strong, Relatively strong,general,weak $)^{\mathrm{T}}=(90,75,60 \text {, Less than60 })^{\mathrm{T}}$.

\section{Confirming each impact factor's weight}

$W=\left(W_{1}, W_{2}, W_{3} \ldots . . W_{\mathrm{n}}\right), n$ is the number, at the same time, it should satisfy the normalization condition. $\sum_{i=1}^{n} w_{i}=1$ 


\section{Constructing the score membership function and fuzzy relation matrix}

First, confirm the membership degree using fuzzy distribution, then confirm the fuzzy relation matrix D using the membership function. $D=\left[\begin{array}{ccc}d_{11} & \ldots . . & d_{1 m} \\ \ldots & \ldots & \ldots \\ d_{n i} & \ldots . & d_{n m}\end{array}\right]$.

Synthesis W and D, calculate the fuzzy comprehensive evaluation vector $\mathrm{H}$, then get the comprehensive evaluation set according each index's weight. The model is: $H=W^{o} D=\left\{W_{1}, W_{2}, W_{3}, \ldots \ldots W_{m}\right\} o\left[\begin{array}{lll}d_{11} & d_{12} & d_{1 p} \\ d_{21} & d_{22} & d_{2 p} \\ & & \\ d_{m 1} & d_{m 2} & d_{m p}\end{array}\right]=\left\{h_{1}, h_{2}, \ldots \ldots h_{p}\right\}$,"o" is the product operation, $h_{\mathrm{j}}$ is the subjection degree of fuzzy subset $V_{\mathrm{j}}$ which is used to evaluate one thing's final grade.

Conversely, we can know the multifactorial comprehensive evaluation by stratifying the elements in the factor set $\mathrm{H}$ by degrees, the model is : $H=\left\{h_{1}, h_{2}, \ldots \ldots . h_{p}\right\}=W o D=W o\left[\begin{array}{l}W_{2} o\left[\begin{array}{c}W_{21} o D_{21} \\ W_{22} o D_{22} \\ \ldots \ldots \\ W_{2 P} o D_{2 P}\end{array}\right] \\ W_{m} o\left[\begin{array}{c}W_{m 1} o D_{m 1} \\ W_{m 2} o D_{m 2} \\ \ldots \ldots \\ W_{m P} o D_{m p}\end{array}\right]\end{array}\right]$

\section{Calculation results}

$$
Z=H V=\left\{h_{1}, h_{2}, \ldots . . h_{p}\right\}\left(V_{1}, V_{2}, \ldots . . V_{P}\right)=\left(Z_{1}, Z_{2}, \ldots . Z_{p}\right)
$$

In this thesis, there are 4 evaluation grades, $\mathrm{p}=4$, strong, Relatively strong, general, weak. The $Z_{1} 、 Z_{2} 、 Z_{3} 、 Z_{4}$ in the magnitude is the corresponding evaluation grade's Weight coefficient .For example, strong means 90 points, Relatively strong means 75 points, general means 60 points, weak means 0 points, so $Z_{1} \times 90+Z_{2} \times 75+Z_{3} \times 60+Z_{4} \times 0$ is the final score of the construction enterprise's ability of technological Innovation. Calculate the final score in turn according to the indexes at all levels, thus dividing the evaluation class of construction enterprises' technology innovation, and this is the final purpose of the study.

\section{Case analysis}

The selected construction enterprise is a construction company in Sichuan province, which is a wholly owned subsidiary of a group co., LTD.First, the three levels indicators established by this article are rated by experts(score with a point value between 1 and 4, respectively mark 4 points, 3 points, 2 points and 1 according to the strong, strong, general, the weak), then through statistics, sorting and analyzing allocation results of experts, get the evaluation results of each index as follows in Table 3. 
Table 3 Evaluation results of third grade index

\begin{tabular}{|c|c|c|c|c|c|c|c|c|c|c|c|}
\hline $\begin{array}{c}\text { third grade } \\
\text { index }\end{array}$ & $\mathrm{C}_{1}$ & $\mathrm{C}_{2}$ & $\mathrm{C}_{3}$ & $\mathrm{C}_{4}$ & $\mathrm{C}_{5}$ & $\mathrm{C}_{6}$ & $\mathrm{C}_{7}$ & $\mathrm{C}_{8}$ & $\mathrm{C}_{9}$ & $\mathrm{C}_{10}$ & $\mathrm{C}_{11}$ \\
\hline weight & 0.571 & 0.286 & 0.143 & 0.667 & 0.333 & 0.667 & 0.333 & 0.584 & 0.232 & 0.184 & 0.455 \\
\hline strong & 0.3 & 0.1 & 0.2 & 0.2 & 0.1 & 0.4 & 0 & 0.2 & 0.3 & 0.5 & 0.2 \\
\hline $\begin{array}{c}\text { Relatively } \\
\text { strong }\end{array}$ & 0.4 & 0.3 & 0.3 & 0.4 & 0.1 & 0.6 & 0.3 & 0.2 & 0.4 & 0.2 & 0.4 \\
\hline general & 0.3 & 0.6 & 0.5 & 0.4 & 0.8 & 0 & 0.7 & 0.6 & 0.3 & 0.3 & 0.4 \\
\hline weak & 0 & 0 & 0 & 0 & 0 & 0 & 0 & 0 & 0 & 0 & 0 \\
\hline $\begin{array}{c}\text { third grade } \\
\text { index }\end{array}$ & $\mathrm{C}_{12}$ & $\mathrm{C}_{13}$ & $\mathrm{C}_{14}$ & $\mathrm{C}_{15}$ & $\mathrm{C}_{16}$ & $\mathrm{C}_{17}$ & $\mathrm{C}_{18}$ & $\mathrm{C}_{19}$ & $\mathrm{C}_{20}$ & $\mathrm{C}_{21}$ & \\
\hline weight & 0.263 & 0.141 & 0.141 & 0.5 & 0.5 & 0.5 & 0.5 & 0.54 & 0.297 & 0.163 & \\
\hline strong & 0.1 & 0.3 & 0.3 & 0 & 0.2 & 0 & 0 & 0.1 & 0.3 & 0.1 & \\
\hline $\begin{array}{c}\text { Relatively } \\
\text { strong }\end{array}$ & 0.6 & 0.4 & 0.4 & 0.3 & 0.6 & 0.5 & 0.4 & 0.7 & 0.3 & 0.4 & \\
\hline general & 0.3 & 0.3 & 0.3 & 0.7 & 0.2 & 0.5 & 0.6 & 0.2 & 0.4 & 0.5 & \\
\hline weak & 0 & 0 & 0 & 0 & 0 & 0 & 0 & 0 & 0 & 0 & \\
\hline
\end{tabular}

According to the analysis above, use the fuzzy statistical method to get the fuzzy comprehensive evaluation matrix $\mathrm{D}_{1}$ of the third grade indexes which is under the second grade index. $B_{1}: D_{1}=\left[\begin{array}{cccc}0.3 & 0.4 & 0.3 & 0 \\ 0.1 & 0.3 & 0.6 & 0 \\ 0.2 & 0.3 & 0.5 & 0\end{array}\right]$.

Select the weighted operator $M(O,+)$ to make the fuzzy calculation about $\mathrm{R}_{1}$, then get $\mathrm{B}_{1}$ 's comprehensive evaluation vector. $\mathrm{H}_{1}: H_{1}=\mathrm{W}_{1} \mathrm{OD}_{1}=\left[\begin{array}{lll}0.571 & 0.286 & 0.143\end{array}\right] \circ\left[\begin{array}{cccc}0.3 & 0.4 & 0.3 & 0 \\ 0.1 & 0.3 & 0.6 & 0 \\ 0.2 & 0.3 & 0.5 & 0\end{array}\right]=\left[\begin{array}{llll}0.229 & 0.357 & 0.414 & 0\end{array}\right]$.

Similarly, we can calculate other second grade index's comprehensive evaluation vector. $H_{2}=\left[\begin{array}{llll}0.167 & 0.300 & 0.533 & 0\end{array}\right], H_{4}=\left[\begin{array}{llll}0.267 & 0.500 & 0.233 & 0\end{array}\right], H_{5}=\left[\begin{array}{llll}0.278 & 0.246 & 0.475 & 0\end{array}\right]$, $H_{6}=\left[\begin{array}{llll}0.202 & 0.453 & 0.346 & 0\end{array}\right] \quad, \quad H_{7}=\left[\begin{array}{llll}0.1 & 0.45 & 0.45 & 0\end{array}\right] \quad, \quad H_{8}=\left[\begin{array}{llll}0 & 0.45 & 0.55 & 0\end{array}\right]$, $H_{9}=\left[\begin{array}{llll}0.159 & 0.532 & 0.308 & 0\end{array}\right]$.

Then we can calculate second grade index's fuzzy comprehensive evaluation matrix. $A_{1}, A_{2}, A_{3}$. $\mathrm{A}_{1}=\mathrm{W}_{1} \mathrm{oB}_{1}=\left[\begin{array}{lll}0.625 & 0.238 & 0.137\end{array}\right] o\left[\begin{array}{llll}0.229 & 0.357 & 0.414 & 0 \\ 0.167 & 0.300 & 0.533 & 0 \\ 0 & 0.5 & 0.5 & 0\end{array}\right]=\left[\begin{array}{llll}0.183 & 0.363 & 0.454 & 0\end{array}\right]$.

Similarly, $\mathrm{A}_{2}=[0.260$ index's fuzzy comprehensive evaluation

$$
N=\mathrm{Wo} A=\left[\begin{array}{lll}
0.528 & 0.332 & 0.140
\end{array}\right] o\left[\begin{array}{llll}
0.183 & 0.363 & 0.454 & 0 \\
0.260 & 0.417 & 0.324 & 0 \\
0.081 & 0.466 & 0.453 & 0
\end{array}\right]=\left[\begin{array}{llll}
0.194 & 0.395 & 0.411 & 0
\end{array}\right]
$$

In conclusion, the company's technology innovation index evaluation result

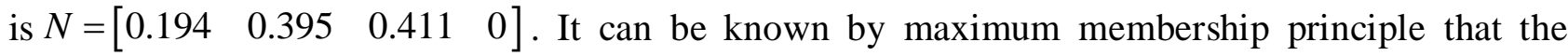


company technology innovation index evaluation membership degree value is 0.411 , because during the evaluation results, the largest of four grades of membership degree is 0.411 . Therefore, the level of evaluation is"general". This result illustrates that the company's technology innovation ability is general, and it still needs to improve its ability to innovate in order to improve the competitiveness of the enterprise.

\section{Conclusion}

In this paper, the construction enterprise technology innovation evaluation has been carried on the preliminary discussion, with the principle of the combination of qualitative and quantitative. And proposed an evaluation index system, which can be more comprehensive, objective and reasonable to reflect the construction enterprises' technology innovation ability. But the construction enterprises' technology innovation evaluation is an extensive and complicated problem, a more in-depth and meticulous research on the evaluation system combined with the actual constantly is still needed.

\section{Acknowledgement}

This research was financially supported by the Innovation Fund of Postgraduate, Xihua University (YCJJ2014091).

\section{References}

[1] Wang Juan, the Diversity of Analytic Network Process's Application Form, Forecast, Vol. 6 (2007), pp.66-68.

[2] Wang Lianfen, Analytic Network Process‘s Theory and Algorithm, Systems Engineering-theory and Practice, Vol. 3(2001), pp.44-50.

[3]Song Zhe, Wang Shuen, Research on the Enterprises's Ability of Performance Management Using Analytic Network Process Method, Science and Technology Management Research, Vol.4(2010), pp.160-163. 